\title{
A DÉL-BUDAPESTI „KÖZLEKEDÉSI JÁTÉK”, AVAGY DÉL-BUDA KÖZLEKEDÉSI PROBLÉMÁINAK STRATÉGIAI JÁTÉK FORMÁJÁBAN VALÓ ELEMZÉSE
}

\author{
(„Transport Game" in Southern Budapest, or the Analysis of the \\ Transport Problems in Southern Buda with a Strategic Game)
}

\section{PALLAI KATALIN}

\section{Bevezetō}

A játékelméleti alapra épülő racionális választások elmélete és politikai döntéselmélet alapvetó problémája, hogy tiszta, matematikai-logikai rendszerben lehetetlen az egyéni preferenciákat olyan, hasonlóan konzisztens társadalmi preferencia rendszerré összegezni, amely ,a racionális elfogadhatóság, akár legelemibb kritériumait is kielégítené"1. (Sen 1995, Arrow 1951) Igy az összegzést a demokratikus intézmény és döntéshozási rendszer tökéletlen mechanizmusa végzi több-kevesebb sikerrel. Budapesten a dél-budai közlekedésfejlesztés heves szakmai és politikai ellentéteket és lakossági ellenállást kiváltó kérdése kitünő alkalom a helyi, demokratikus döntéshozási rendszer elemzésére.

A Lágymányosi híd megépülése utáni helyzetben a hidat az autópályákkal összekötő közúti kapcsolat kérdésében szakmailag egyértelmủ döntést lehetett hozni, ami messzemenỏen egybeesett a megvalósító ơnkormányzat, és az őt megválasztó lakosság túlnyomó tőbbségének érdekével. Vagyis, ha a preferenciák a tényleges érdekeket tükröznék és létezne objektíven aggregált közösségi választás, az eredménye biztosan tudható lenne ebben az esetben. Ennek ellenére az elmúlt években a helyi politikai csatározások eredményeképpen erösen sub-optimális lépések történtek. $\mathrm{E}$ történet stratégiai játék formájában való elemzése kiváló alkalom a kialakult helyzet (esetünkben a probléma), a lehetséges megoldás, és a szereplők stratégiáinak elemzéséhez, a politikai piacok elmélete (Political Market Theory) ${ }^{2}$ pedig kitünó eszköz a demokratikus és decentralizált rendszerben a szereplök érdekeinek és lehetséges lépéseinek megértéséhez. Tanulságos továbbá, hogy a rendszerváltás következtében megváltozott politikai küzdőtér mennyiben változtatta meg az elért eredményeket, és milyen új megoldásokat hozott.

A játékelméleti elemzés a lehetséges stratégiák vizsgálata mellett a várható eredményt (esetünkben a lehetséges végkifejletet) próbálja meghatározni. Elemzéseiböl kiderül, hogy milyen stratégiák alkalmazása esetén, milyen eséllyel tudják a szereplők érdekủket érvényesíteni. Láthatóvá válik az is, hogy a játék mely kimenetele, milyen stratégiával akadályozható meg (amennyiben egyáltalán létezik ilyen stratégia). E ponton lehet az elméleti modell eredményét gyakorlati tanáccsá visszafordítani a kiválasztott stratégiát megvalósító eszközök megalkotásával és alkalmazásával.

Az elemzés a megértés és modellezés gondolati kalandjának gyönyörüsége mellett - eredményessége esetén - igy azt a gyakorlati célt is szolgálhatja, hogy - amennyiben létezik - elfogadható megoldás, az lehetőleg a legkevésbé ,kacskaringós" (így pazarló) úton érvényesüljön. 
Pallai Katalin : A dél-budapesti „közlekedési játék”,

avagy Dél-Buda közlekedési problémáinak stratégiai játék formájában való elemzése

Tér és Társadalom 12. évf. 1998/3. 133-151. p.

134 Gyors ténykép

TÉT XII. évf. 1998 - 3

\section{A történet}

Budapest úthálózatában az elmúlt évtizedekben egyre súlyosabbá vált a gyürü irányú elemek hiánya. Amikor döntés született - a rendszerben a Kiskörút és Nagykörút után következő - Hungária körút korszerü kiépítéséról ritka kedvezö körülmény volt, hogy az új körút helyét Pesten a múlt század óta, a budai folytatás Hamzsabégi úti szakaszát e század eleje óta városrendezési szabályozás védte. Hosszú előkészítő munka után 1987-ben az Állami Tervbizottság is eldöntötte a Lágymányosi híd építésének 1989-es kezdését. (Dalmy 1995) Az új híd Pesten, a terv szerint a Hungária körúthoz kapcsolódott, a budai oldalon pedig a Hamzsabégi úton, a vasúti töltéssel egy szinten, vele közös, új zajvédelmi folyosóban vezette volna ki az M1M7-re a XI. kerület szempontjából átmenő forgalmat. Így megszüntethetővé vált volna a Budaörsi út-Nagyszöllós út kapcsolat, és a Bocskai út-Karolina útvonal az autópálya forgalmától mentesülve, csillapított forgalmú, belső körúttá válhatott volna. (1. ábra)

E megoldás - a beruházó gondolatmenete szerint - a város közlekedési hálózatának szempontjából optimális volt, hiszen a Hungária körúttal elérhetỏ maximális belső területi csillapítást eredményezte volna azzal, hogy a tranzit forgalom számára jóval kedvezőbb - így bizonyosan igénybevett - alternatívát biztosított volna a városközponton való áthaladásnál. Ugyanakkor a lehető legrövidebb, és egyetlen olyan lehetőséget használta volna ki, ahol lényegében csomópontmentes - így akadály és torlódás-minimalizáló - és környezeti szempontból védett folyosóban, minden lehetséges terhelési határértéket betartva lehetett volna átvezetni a lakóterületen keresztül a forgalmat.

Az előző indoklás csak „,sötét-zöld” elvek alapján támadható, amit kezdettől a Levegő Munkacsoport képviselt. E szerint a közlekedés, mint kereslet-kínálati viszony mủködik. Minden útépítés új forgalmat generál, így a nagy forgalmú utak létesítése (így Hamzsabégi út megépitése, vagy a térségben bármely más út szélesítése) elfogadhatatlan, helyette korlátozni kell a forgalmat, vagyis a városba az autóval való bejutást. E gondolatmenet ilyen radikális formában, városi szinten a világon mindenütt csak az alternatív ellenzék oldaláról merül fel. Budapesten azért nevezhető ez a nézet sötétzöldnek, mert az elmúlt évtizedben a motorizáció késleltetett és rendkivül gyors növekedése következtében jelentkező „,kereslet” erősen meghaladta a „kínálatot", vagyis a nagyon hiányos úthálózat kapacitását. Ebben a helyzetben e drasztikus lépés realitását lényegében minden más szakmai vélemény megkérdőjelezi, és komoly gazdasági és politikai árára hivja fel a figyelmet.

A beruházás a Hamzsabégi úton közvetlenül, mintegy háromezer embert érintett volna, akik az útvonal mellett laknak. Mivel az útvonal szabályozása jóval a házak épitése elött megtörtént, így a tulajdonjogok kezdettől az építkezés utáni állapotnak megfelelően rendeződtek.

A döntés ellen, a rendszerváltó idők kezdetén, 1988-89-ben jelentkezett bizonyos lakossági ellenállás, ami azonban 1990-re annyiban rendeződött, hogy az érintettek 80\%-a az építkezést elfogadta. 
Pallai Katalin : A dél-budapesti „közlekedési játék”,

avagy Dél-Buda közlekedési problémáinak stratégiai játék formájában való elemzése

Tér és Társadalom 12. évf. 1998/3. 133-151. p.

1. ÁBRA

Dél-Budapest közlekedési hálózata - tervezett állapot

(The transport network of South-Budapest - planned state)

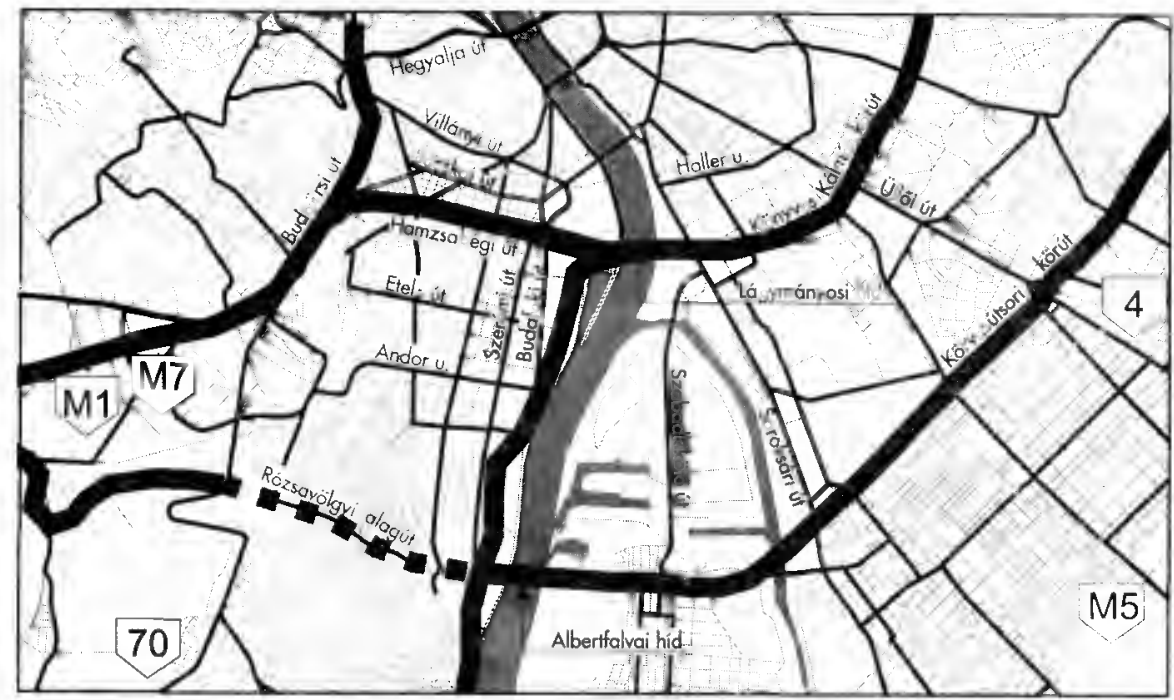

2. ÁBRA

Dél-Budapest közlekedési hálózata-jelenlegi állapot

(The transport network of South-Budapest - current state)

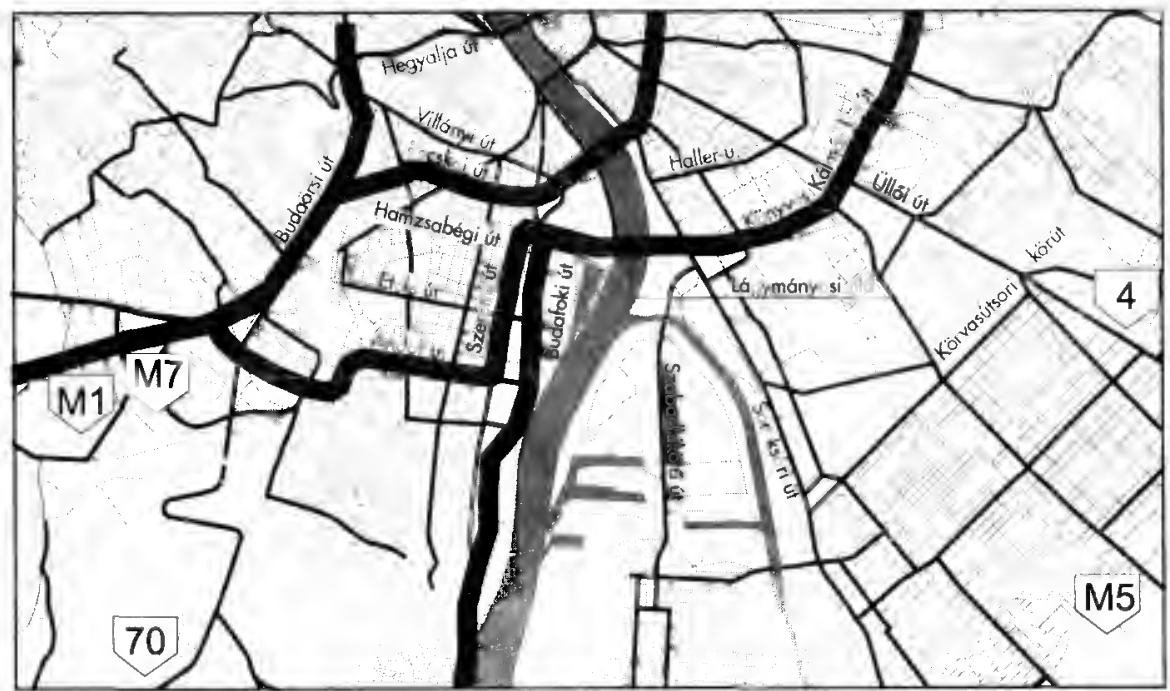

Forräs: Budapest térkép alapján saját szerkesztés 


$$
\text { A játék első szakasza - 1990-91 }
$$

\section{Helyzet 1. - 1990-91}

1990-ben új fejezet kezdödött a Hamzsabégi út tơrténetében, amikor új játékosok jelentek meg: szavazatokért küzdö helyi politikusok és az új játékszabályok szerinti küzdelemben tapasztalatlan önkormányzatok. A most már tisztán „politikai” küzdelemben az önkormányzati bürokrácia és hivatalos szakértőik erőtlenül védték a korábbi koncepciójukat, a maguknak nevet szerezni próbáló politikusok és a korábban háttérbe szorult szakértők egy része pedig különbözö gondolatmenetek alapjản vetették el azt és javasoltak újakat.

\section{A játékosok}

A választók/lakosság

A politikai piacra vonatkozó elméletek (Political Market Theories) lényegében egyetértenek abban, hogy a választó racionálisan alulinformált ${ }^{3}$, mert a döntésekhez megfelelỏ információ beszerzésének költsége messze meghaladja azt a hasznot, amit lényegében jelentéktelen, egyetlen saját szavazatával realizálni tud a politikai küzdelemben. (Downs 1959) Bizonyos, hogy amennyiben a politikailag meglehetösen közömbös átlagos budapesti polgárt tekintjük szavazónak, e kérdéskörben - vagyis, hogy hol optimális levezetni a Lágymányosi híd forgalmát - ôt ténylegesen alulinformáltnak feltételezhetjük.

A lakosságnak általában csak elenyészỏen kis része érdeklỏdik a város- és közlekedéspolitika nagyhálózatainak elvi problémái iránt, túlnyomó többségüket annyi érdekli, hogy minél kevésbé zajos és bủzös helyen éljen, vagyis a lokális környezeti minöség, valamint hogy minél kényelmesebben és gyorsabban eljusson céljaihoz, vagyis a közlekedési hálózat hatékonysága.

Amennyiben a lakossági érdekeket vizsgáljuk - attól függetlenül, hogy mennyire tudatosulnak - a probléma fenti leírásából érthetö, hogy a nem-Hamzsbégi úti választónak érdeke a Hamzsabégi út megépitése, mert a kedvezöbb városfejlödésen keresztul áttételesen számára is közvetett haszon realizálódik. A lakosság azon része számára, aki az M1 vagy $\mathrm{M} 7$ autópályát gyakrabban használja, érdekként jelentkezik a torlódásmentes, gyors be- és kivezetés is. Ezt a közvetett hasznot a Hamzsabégi úti lakos is élvezné, de számára várhatóan erösebben esik latba az út káros, környezeti hatása, ami a megépítendö védelem ellenére is rontja lakókörnyezetét. Így e kis ( $\mathrm{kb} .3$ ezer fös) lakossági csoport a beruházást várhatóan negatívan értékeli.

A fentiek értelmében, a pár érdekelt és érdeklödőn kívüli átlagpolgárról feltételezhetjük, hogy közömbössége megvédi attól, hogy e számára alig érzékelhető, közvetett haszonra felfigyeljen. Ezzel szemben az érintett kisebbség érdeklödése felkelthetö. 
Pallai Katalin : A dél-budapesti „közlekedési játék”,

avagy Dél-Buda közlekedési problémáinak stratégiai játék formájában való elemzése

Tér és Társadalom 12. évf. 1998/3. 133-151. p.

\section{A politikusok}

Az elmélet szerint a politikus érdeke hogy megválasszák. Ehhez a választók kedvében kell járnia. A politikusok pártokat alakítanak, hogy közös esélyüket maximalizálják a választásokon. (Downs 1959) A választások közötti időben a pártokon belül belső hatalmi harcok is zajlanak, ami bizonyos mértékben megoszthatja a tagokat, és újrarendezi az erőviszonyokat.

A politikusok és pártok egyes kérdésekben gyakran kevésbé informáltak, mint azt a naiv polgár feltételezi, azt azonban tudják, hogy a választók még kevésbé vannak tisztában a döntések körülményeivel, és megfelelö eszközökkel véleményük befolyásolható. Végül a választásoknál a győzelemhez az adott helyzet szerinti, kialakult választói vélemények mellé kell állni. Vagyis a politikus annak a polgárnak a szavazatát nyeri el, akinek a véleményét hirdeti. Így elegendően kis választókörzetek esetén, a többség szempontjából aránylag partikuláris érdekek képviselete is győztes stratégia lehet.

\section{A bürokrácia}

A bürokrácia jelen esetben a politikai döntés kivitelezöje. Érdeke, hogy munkáltatójával ne kerüljön szembe, állását és későbbi elöléptetésének lehetőségét biztosit$\mathrm{sa}^{4}$. (Niskanen 1971) Sem érdeke, sem lehetösége nincs az érdemi konfrontációra, sem a lakosokkal, sem a politikusokkal szemben.

A jelenlegi rendszerben a hivatalnok teljesítménye nem tényleges „hatékonysági alapon", vagyis az általa elköltö̈tt pénz hasznosulása szerint mérỏdik. A költségvetési rendszer csak a ráfordított pénzek mennyiségét (input adatokat) teszi láthatóvá ${ }^{5}$, amelyek növekedése a hivatal érdeke, hiszen az ágazat presztízsét növeli. (Cullis and Jones 1992) (Az output adatokat, vagyis a „teljesítményt” csak külön monitoring rendszer mérhetné, aminek még nyomai sem látszanak ma az önkormányzatok fejlesztéseinél.)

İgy a bürokrácia és az általa alkalmazott szakértök bár az optimális döntésekhez szükséges információknak várhatóan tudatában vannak ${ }^{6}$, abból csak annyi épül be a döntési folyamatba, amit a közvetlen szereplőkön (választók és politikusok) keresztül érvényesíthetnek.

Elvben így e csoport számára két út létezik: az egyik a politikai akarat fegyelmezett, fenntartás nélküli, „,kivitelezése”, a másik, a hivatali fegyelem adta lehetőségeken belül, a meggyözés korlátos eszközével a meggyóződése szerinti ,jó útért" küzdeni?

\section{Stratégiák az elsö szakaszban}

Az elsỏ önkormányzati választások alatt a jelöltek és pártok üzenetei a Lágymányosi híd és Hamzsabégi út problémájánál sokkal általánosabb szinten mozogtak. $\mathrm{Az}$ újonnan megválasztott politikusok azonban gyorsan kiadták megrendeléseiket azoknak a szakértőknek is, akik a nagyberuházások döntéseinek elökészítésében addig háttérbe szorultak. Színesedett így a szakmai álláspontok skálája, és tökéletes újrakezdési hangulat alakult ki, melyekben kezdetben elvi alapjukban és kivitelezhetóségưkben gyökeresen különbözó vélemények látszólag azonos súllyal szerepeltek. A legalapvetőbb probléma a reális lehetỏségek felmérése volt, amit az újoncok nehezen tanultak. 
Pallai Katalin : A dél-budapesti „közlekedési játék”,

avagy Dél-Buda közlekedési problémáinak stratégiai játék formájában való elemzése

Tér és Társadalom 12. évf. 1998/3. 133-151. p.

A kezdeti kavarodásban - a forgalmat drasztikusan korlátozó, agresszívebb zöld elvek is a szokásosnál nagyobb hitelt szereztek maguknak, és élénk vita alakult ki arról, hogy mennyire reális a forgalmat a városból kiszorítani, vagyis, hogy mi lenne az új déli Duna-híd optimális helye ${ }^{8}$. (3. ábra)

Megindult a helyi politikusok harca is a mind nagyobb hatalomért, amit e vitákon való aktív részvétellel arányosan növekvő hírnevükkel és lakossági támogatásuk erösítésével próbáltak megszerezni. Objektíven bebizonyítani alig lehet, hogy a vitákban képviselt, esetenként erösen megkérdőjelezhetö álláspontok mikor voltak a kezdő politikus tudatlanságának, és mikor csak egyszerú szavazatszerzỏ manőverének következménye.

\section{A választók/lakosság}

$\mathrm{Az}$ átlag budapesti polgár esetében az elmélet beigazolódott: a Lágymányosi híd forgalmának levezetése közömbösségét és alulinformáltságát nem törte meg.

A Hamzsabégi úti lakosok egy része, akik a beruházást logikusan negatívan értékelték, a fejlesztést ellenző zöldek által meggyőzhető volt, hogy érdekéért fellépjen és tiltakozzon.

A legérdekesebb csoport azonban a kissé távolabb lakó Bocskai útiak voltak - akik bár közvetlenül és közvetve is nyertek volna a Hamzsabégi út kiépítésén, mert az ő környezetük forgalma csillapodott volna -, félreinformáltságuk és egyéni politikai érdekek által való befolyásoltságuk miatt a leghangosabb tiltakozókká váltak.

Az ellenzők tevékenysége az érdekcsoport legegyszerübb müködése volt: a könynyen érthetỏ cél - hogy „ne építsenek Hamzsabégi utat” - jól artikulálható, és jól tudja szervezni a kis csoportot, akik vélt, vagy igazi közvetlen érintettségük miatt számukhoz képest arányában sokkal nagyobb hatást tudtak elérni ${ }^{9}$. (Stevens 1993) A hatást az is nơvelte, hogy e tiltakozás résztvevői szinte az egyetlen szervezett lakossági csoportot jelentették akkor Budapesten, így véleményük némi csúsztatással a „lakosság” véleményeként volt használható.

\section{A politikusok}

Az önkormányzati választások után a helyi politikusok belsö hatalmi kủzdelmeikben próbálták magukat erősíteni, tudva, hogy ez négy év múlva az újraválasztásnál fontossá válhat, és kulcs lehet ahhoz is, hogy az országos küzdỏtérre „felkeriulhessenek". A választás után a pártok egysége így logikusan megbomlott és az egyéni hatalom-maximalizálás lépett elöre.

A XI. kerület két részre oszlott: a Hamzsabégi út építéséröl véleményt nem nyilvánító közömbösek és egyetértők és az egyre hangosabb, „ellenzők” táborára. A kerületi politikusnak, önmaga meg- és elismertetéséhez kiváló alkalom volt az „ellenzó" lakosok tiltakozása mellé állni. Fövárosi szinten a politikai harc sokkal inkább elvi alapon zajlott.

A közvetlenül, kellemetlenül érintett, kb. 3000 fös csoportot képviselni kívánó politikus számára természetes nyereség volt a tiltakozás. A Hamzsabégi út beruházója a Föváros lett volna, és engedélyezöje a kerület. Így a kerületi politikusnak jó esélye volt az „eredményes harcra”: a tiltakozás nem sértette a kerületi célkitüzéseket, vagyis nem „saját programját” vétózta meg, az összvárosi előny pedig objektíven nem mérhetố kategória. Igy a helyi politikusnak jó esélye volt a késleltetésre és a költségesebb alternatív megoldást a Fővárosnak kellett finanszíroznia. 
Pallai Katalin : A dél-budapesti „közlekedési játék”,

avagy Dél-Buda közlekedési problémáinak stratégiai játék formájában való elemzése

Tér és Társadalom 12. évf. 1998/3. 133-151. p.

TÉT XII. évf. 1998 — 3

Gyors ténykép

\section{3. ÁBRA}

Budapest úthálózata

(Road map of Budapest)

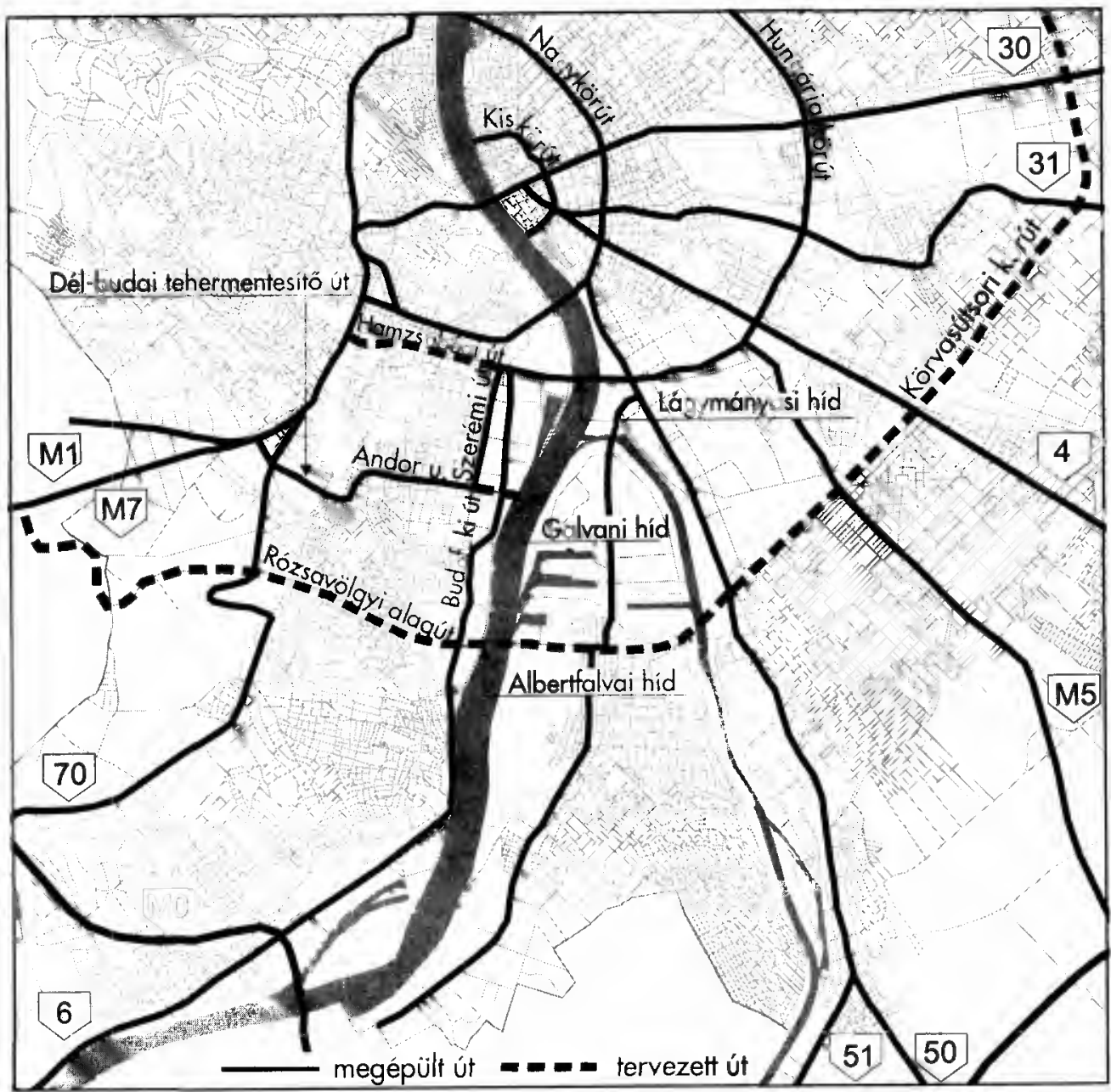


Pallai Katalin : A dél-budapesti „közlekedési játék”,

avagy Dél-Buda közlekedési problémáinak stratégiai játék formájában való elemzése

Tér és Társadalom 12. évf. 1998/3. 133-151. p.

A megvalósuló beruházás következtében elvileg „nyertessé” váló, közvetett környezetet képviselö, önmagában még bizonytalan helyi politikusnak is sokkal kisebb kockázatot jelentett a zöldek által feltüzelt lakossági tiltakozás mellé állni, mint a már némileg hiszterizált lakosságot az összvárosi elöny kőzvetett hasznáról meggyözni. Így a ténylegesen ,,veszteseknél” nagyobb erő állt a tiltakozás mellé.

Fövárosi szinten ekkor a csatározások Budapest általános várospolitikai kérdéseinek elvibb szintjén zajlottak. A vita a közlekedéspolitikában az ún. „zöld” és ún. „technokrata beton lobby” végletei közötti kompromisszumot kereste, és a nagy összeưtközés a föhálózat és a hidak kérdésében volt, így a forgalomnak a hídról való levezetésének kérdése a figyelemben hátrébb szorult. A hidak kérdésében az erőviszonyokat jól mutató megoldás született: a Közgyülés elfogadta az alternatív álláspontot, hogy Délen nem egy, hanem három hídra van szüksége a városnak, forráshiány miatt azonban egyenlöre csak egy, a Lágymányosi híd épül meg, így ebböl a szempontból az eredmény gyakorlatilag változatlan maradt, és a híd építése megindulhatott.

Az összvárosi szempontból logikusan került második sorba a levezetés kérdése. Így azonban a megoldást szinte teljesen a helyi eróviszonyok döntỏtték el, aminek következtében a Fôváros nemcsak elvesztette a Hamzsabégi út ügyét a jobban érdekelt helyi politikával szemben, de politikai szinten vélhetōen az sem tudatosult, hogy a kialakult, Délbudai tehermentesitő út alternatívájának megvalósítása lehetetlen.

\section{A bürokrácia}

A bürokrácia, mint a politikai döntések kivitelezője müködött. Bizalmi viszony nem alakult ki az új politikus és hivatala között, így a szakmailag nyilvánvaló tényt, hogy a "Délbudai tehermentesítô út - Andor utcai" döntés nem megoldás, nem tudta hitelt érdemlően közvetíteni.

\section{A , kimenetel" az elsô szakaszban}

A vita látszólag - témánk szempontjából fontos elemeiben - a kơvetkező döntéssel zárult: a fỏvárosban a jövőben három híd épül Délen a Petőfi és az M0 hídja között, amelyek között az első a Lágymányosi híd lesz, ami a tervezett $2 \times 3$ helyett $2 \times 2$ sáv + villamossal épül, majd „kőzel azonos idóben” a Galvani híd épül meg. Nem épül ki a Hamzsabégi út, helyette a híd budai kapesolatát a Szerémi út és a Délbudai tehermentesítő út (és Andor utca) fogja megteremteni. E döntést a Fövárosi Közgyúlés 1991-ben és a Parlament 1992-ben elfogadta, igy megindulhatott a Lágymányosi híd épitése.

A döntés irracionalitása a következőkben állt: jól lehetett tudni már akkor is, hogy csak egy dél-budapesti hídra lesz forrás a közeljövöben, hogy nincs se forrás, se forgalmi igény a villamosra, hogy a forgalom átvezetése az Andor utcán a környezeti határterhelések betartásával nem oldható meg, és ott jogos tiltakozás várható.

A döntés eredménye lett, hogy „, a budai oldal hálózata egy föirány nélküli szétosztó hálózattá alakult" (Schulek 1995), ami a forgalomból következő környezeti terhelést növelte és jóval nagyobb - és föleg lakóterületre - terítette szét, a korábbi 3 ezer helyett kb. 27 ezer lakost érintve ${ }^{10}$. A továbbra is hiányos és torlódásos rend- 
Pallai Katalin : A dél-budapesti „közlekedési játék”,

avagy Dél-Buda közlekedési problémáinak stratégiai játék formájában való elemzése

Tér és Társadalom 12. évf. 1998/3. 133-151. p.

szer lényegesen kevésbé kedvező alternatíva a tranzit forgalom számára, így a Belváros tehermentesítése is kevésbé érvényesül.

E 199 l-es đöntés következtében így a három korábban kitüzött fejlesztési cél közül mindhárom erösen sérült, vagyis az érdekek harca a politikai piacon szakmai szempontból a korábbinál kevésbé kedvezó megoldást hozott létre. A további lépések elemzése érdekében érdemes megvizsgálni a szereplöket már ezen a ponton, hiszen motivációik fỏ elemei a következőkben sem változnak alapvetően. Így ha itt sikerül a lépéseket és történéseket indokló képet adni, az várhatóan a későbbiekben is használható lesz.

\section{A játékosok eredményei az első szakaszban}

\section{A választók / lakosság}

Az átlag budapesti polgár érdeke elvben sérült, a kevésbé hatékony megoldással, és személyesen is érintetté vált, amikor azt az útvonalat kívánta használni. Ennek ellenére valószinüleg mindezt alulinformáltsága miatt nem realizálta.

A Hamzsabégi úti lakosok személyes szinten nyertek lakókörnyezetük megvédésével. E nyereség lényegesen meghaladta azt az elvi veszteséget, amit az összvárosi hálózat kára jelentett számukra.

Az Andor utcaiak vesztettek a legtöbbet, mert közvetlen kömyezetük is romlott, és a hálózat is rosszabb lett. A többi XI. kerületi lakos - annak ellenére, hogy sokuk győztesnek érzi magát - szintén vesztett, mert a forgalom a kerületben jobban szétterült, ami öket is zavarja.

\section{A politikusok}

A kerületi politikus személyes karrierjét esetenként megalapozta e kezdeti csatározásokban, így bizonyosan nyertese volt az elsö fordulónak.

A fövárosi politikus megítélése nem igazán itt dölt el, de rendelkezésére álló fejlesztési keretből jóval nagyobb összeget kellett már eddig is áldoznia e területre, mint amibe a Hamzsabégi út került volna és a választók elismerését kiváltó, jó megoldás hasznát nem élvezhette. Így mind az alternatív költség, mind az elmaradt haszon alapján ö is inkább vesztes.

\section{A bürokrácia}

A bürokrácia mindenképpen vesztes, mert végig kellett asszisztálnia a számára, szakmailag nyilvánvalóan irracionális folyamatot.

\section{Értékelö táblázatok}

A "játékosok", vagyis az érintettek eddigiekben logikusan végiggondolt " eredményeit", vagyis a kialakult helyzetböl származó elönyeiket és hátrányaikat most értékelő táblázatokban összegezzük.

Az értékelő táblázatok egy "gondolati játék" részei. Azt a stratégiai játékot modellezik, amelyben bármely döntéshozó a szereplök érdekeinek és preferenciáinak feltárása és az adott politikai dỏntéshozási rendszer ismerete alapján, megtalálhatná 
Pallai Katalin : A dél-budapesti „közlekedési játék”,

avagy Dél-Buda közlekedési problémáinak stratégiai játék formájában való elemzése

Tér és Társadalom 12. évf. 1998/3. 133-151. p.

azt a javaslatot, ami az optimális kompromisszumot jelenthetné a közlekedéshálózati logika és a politikai realitás között.

Az itt létrehozott táblázatok több szempontból szakitanak a korábban idézett elméletekben lefektetett szabályokkal. A társadalmi választások elmélete szerint lehetetlen lenne a preferenciák erőssége szerint differenciálni ${ }^{11}$ vagy a lakossági csoportok közös választásait pontosan összegezni ${ }^{12}$, a vélt és tényleges érdekeket megkülönböztetni ${ }^{13}$. Továbbá bármely elmélet szerint a táblázatokba a szereplők által ténylegesen kinyilvánított, és nem egy szerző által "feltételezett" preferenciáknak kellene kerülnie.

Jelen esetben azonban mindez megengedhetö, mert az írás célja nem a következő Nobel díjra aspiráló alapkutatás, vagy konkrét vizsgálatokkal megalapozott tényleges politikai tanácsadás. A cél mindössze különböző tudományágak elemeinek egy adott gyakorlati probléma megoldására alkalmas, újszerü modellbe rendezése annak bemutatására, hogy a módszer - a szükséges vizsgálatok tényleges elvégzése esetén alkalmas lehet a legkülönbözőbb konfliktusszituációkból a lehetséges kivezetó stratégiák megtalálására.

A továbbiakban az értékelö táblázatokban a következỏ pontrendszert használjuk:

\section{TÁBLÁZAT}

Az egyes érdekek érvényesülésének pontértékei

(The Scores of Effectiveness of Individual Interests)

\begin{tabular}{|l|c|c|}
\hline & $\begin{array}{c}\text { Érvényesülés } \\
\text { pontértéke }\end{array}$ & $\begin{array}{c}\text { Nem érvényesülés } \\
\text { pontértéke }\end{array}$ \\
\hline Fontos személyes érdek & +5 & -5 \\
\hline Kevésbé fontos személyes érdek & +3 & -3 \\
\hline Közvetett érdek & +1 & -1 \\
\hline Közömbös & 0 & 0 \\
\hline
\end{tabular}

Forrás: sajảt adatok.

Az első periódusban (1990-1991-ben) a kérdés két alternatíva közötti választásként merült fel: megépül a Hamzsabégi út, vagy nem épül meg. A, „nem épül meg” végül is az Andor utca átépítését jelentette, de ezt nem mindenki fogta még akkor fel. Így először a „megépül"/"nem épül" kérdést kell vizsgálni:

\section{TÁBLÁZAT}

Az egyes érdekcsoportok érdekeltségének mértéke

(The Degree of Interest of Individual Concerns)

\begin{tabular}{|l|c|c|}
\hline Érdekcsoport & Hamzsabégi épül & H nem épül \\
\hline Átlag budapesti lakos & +1 & 0 \\
\hline Hamzsabégi úti lakos & -5 & +5 \\
\hline Andor utcaí lakos & +1 & -1 \\
\hline Többi XI. kerületi lakos & +1 & -1 \\
\hline Kerületi politikus & -5 & +5 \\
\hline Fövárosi politikus & +3 & -3 \\
\hline Hivatal & +3 & -3 \\
\hline
\end{tabular}

Forrás: saját adatok. 
Pallai Katalin : A dél-budapesti „közlekedési játék”,

avagy Dél-Buda közlekedési problémáinak stratégiai játék formájában való elemzése

Tér és Társadalom 12. évf. 1998/3. 133-151. p.

A preferenciák ilyen pontozásának eredménye hasonló a valós helyzethez, ahol a legintenzívebb véleménye a Hamzsabégi úti lakosnak és az ő elégedetlenségüket kihasználó helyi politikusnak volt.

A következö táblák azt a hipotetikus helyzetet próbálja értékelni, hogy mi lehetett volna, ha nem az „épül a Hamzsabégi út” vagy „nem épül” típusú kérdés vetödött volna fel, hanem a választás a tényleges alternatívák között tờrtént volna, vagyis „Hamzsabégi út”, vagy „Andor utca” épül, a lakosok megfelelö elözetes tájékoztatása után.

\section{TÁBLÁZAT}

Az egyes érdekcsoportok érdekeltségének mértéke ténylegesen megnevezett alternativák esetén

(The Degree of Interest of Individual Concerns, in the Case of Alternatives are Defined in Deed)

\begin{tabular}{|l|c|c|}
\hline Érdekcsoport & Hamzsabégi épül & Andor épül \\
\hline Átlag budapesti lakos & +1 & 0 \\
\hline Hamzsabégi úti lakos & -5 & +3 \\
\hline Andor utcai lakos & +5 & -5 \\
\hline Többi XI. kerületi lakos & +3 & -1 \\
\hline Kerületi politikus & +3 & +3 \\
\hline Fővárosi politikus & +3 & -3 \\
\hline Hivatal & +3 & -3 \\
\hline
\end{tabular}

Forrás: saját adatok.

E "hipotetikus" táblák pontjaiból látható, hogy a fejlesztés kérdése a korrekt kérdésfeltevés, és megfelelö elözetes tájékoztatás esetén valószinüleg nem terelödhetett volna zsákutcába, mert akkor a legerösebben érdekelt csoport az Andor utcai lett volna és már a helyi politikusok közül is csak az állhatott volna a tiltakozás mellé, aki elvállalja az Andor utcai érdeket, a kerület többi lakójával, tehát más helyi érdekkel szemben. Innen propagandával is nehezebb lett volna a nagyobb - és elözetesen már más irányba tájékoztatott - csoport véleményét befolyásolni egy nem elfogadó kerületi konszenzus irányába.

$$
\text { A játék második szakasza-1997-98 }
$$

Helyzet II. - 1997-98

A rendszerváltás után néhány év alatt lényegében kialakult az új várospolitikai és közlekedésfejlesztési koncepció, melyröl, ha Közgyúlési döntés nem is született, föbb elemeiben elfogadottnak tekinthetö.

A kilencvenes évek Fóvárosi fejlesztései közül az egyik legfontosabb volt a Hungária körút kiépítése, és a déli, budai kapcsolatát megteremtő Lágymányosi híd. E fejlesztések befejezése alapvetó feltétel a városfejlesztés legfontosabb stratégiai céljainak megvalósításához: a belvárosi forgalomcsillapításhoz, a környezeti állapot javításához és a külsỏ közlekedési hálózat hiányainak enyhítéséhez, így mind a város kủlső, mind belső területeinek rehabilitációjához. A Lágymányosi hídnak és kapcsolódó úthálózatának alapvető feladata, hogy lehetőséget adjon a Belváros szempontjából a tranzit forgalom központot elkerülő vezetésére. A Hungária körút 
Pallai Katalin : A dél-budapesti „közlekedési játék”,

avagy Dél-Buda közlekedési problémáinak stratégiai játék formájában való elemzése

Tér és Társadalom 12. évf. 1998/3. 133-151. p.

kiépítése a befejezéséhez közeledik, a Lágymányosi híd készen áll, a budai oldal országos és nemzetközi föforgalmi útjaival való lehetséges kapcsolatai azonban még mindig heves viták tárgyát képezik.

Mára a Dél-budai tehermentesitö út $2 \times 2$ sávban megépült ugyan, de az is bebizonyosodott, hogy az 1xl sávos Andor utca nem alkalmas a Lágymányosi híd forgalmának levezetésére. Óriási a környezeti teher, ami még $2 \times 2$ sávos kiépítés esetén sem lenne az engedélyezett határértékre csökkenthetö, így az építéshez az ÁNTSZ a szakhatósági engedélyt megtagadta. Az Andor utcán az úttest mellett megfelelö környezetvédelmi árnyékolás sem épithetö ki. Így a helyi lakosok tiltakozása a kialakult helyzet ellen logikus és jogos.

Amennyiben a forgalmat az Andor utca korlátozásával az M0 és 6-os útra próbálnák terelni, a jelentősen megnövekedett úthossz miatt, a racionális vezetö minden más alternatívát és utat igénybe venne, a terhelést szinte a teljes XI. kerületi területen szétterítve és továbbra is a Belvárost is keresztezve.

A legkritikusabb teherforgalom kitiltására elvben elképzelhető a 6-os út bevezető szakaszának és híd kapcsolatának $2 \times 2$ sávosra bövítése, ez azonban évekig tart. Igazi javulást esetleg az M0 teljes keleti szakaszának kiépülése hozhat, amikor e dél-budai szakasz budai célforgalomra módosulhat.

A Galvani híd lekerült a napirendröl, és az Albertfalvai híd is csak 20 éves távlatban reális.

Egyre nyilvánvalóbbá válik, hogy a kialakult közlekedési krízis oldása és a belső városi forgalomcsillapitás csak a Hamzsabégi út kiépítésével érhető el. Az igazi kérdés így az marad, hogy mi módon lehetséges „politikailag” a Hamzsabégi úti megoldásig visszajutni.

\section{A lehetséges kimenetelek a második szakaszban}

1. Hamzsabégi út kiépítése + Szerémi $2 \times 2+$ Andor $2 \times 2$ csak személygépkocsira + teherforgalom kiszoritása M0 és 6-os bevezető $(2 \times 2)$, Budafoki útra, majd M0 kelet kiépülése után csak budai, teher célforgalom.

2. Hamzsabégi út kiépitése + Andor $1 \times 2+$ Szerémi $1 \times 2+$ teherforgalom kiszorítása M0 és 6-os bevezető $(2 \times 2)$, Budafoki útra, majd M0 kelet kiépülése után csak budai, teher célforgalom.

3. Hamzsabégi út nem + Szerémi $2 \times 2+$ Andor $2 \times 2$ csak személygépkocsira + teherforgalom kiszorítása M0 és 6-os bevezetö $(2 \times 2)$, Budafoki útra, majd M0 kelet kiépülése után csak budai, teher célforgalom.

4. Hamzsabégi út nem + Szerémi $1 \times 2+$ Andor $1 \times 2+$ Albertfalvai híd + erös korlátozások, a teherforgalom kiszorítása M0 és 6-os bevezető, Budafoki útra, majd M0 kelet kiépülése után csak teher célforgalom.

Elvben még két változat lenne lehetséges:

A. Hamzsabégi út + Szerémi $2 \times 2+$ Andor $2 \times 2$ (Rózavölgyi alagút kivezető útjára kötve) + Albertfalvai híd + Rózsavölgyi alagút közvetlen autópálya kapcsolattal + erős korlátozások, a teherforgalom kiszorítása M0 és 6-os bevezetö $(2 \times 2)$, Budafoki útra, majd M0 kelet kiépülése után csak budai, teher célforgalom.

B. Hamzsabégi út nem + Szerémi 1 22 + Andor $1 \times 2$ + Albertfalvai híd + Rózsavölgyi alagút nem + erős korlátozások, a teherforgalom kiszoritása M0 és 6-os bevezetö ( $2 \times 2)$, Budafoki útra, majd M0 kelet kiépülése után csak budai, teher célforgalom. 
Pallai Katalin : A dél-budapesti „közlekedési játék”,

avagy Dél-Buda közlekedési problémáinak stratégiai játék formájában való elemzése

Tér és Társadalom 12. évf. 1998/3. 133-151. p.

Tudni kell azonban, hogy a Hamzsabégi út, Andor utca és Szerémi út tervei lényegében bármely változatra készen állnak, és elfogadásuk esetén az építkezések azonnal elkezdhetóek és aránylag gyorsan lebonyolíthatóak. Ezzel szemben az Albertfalvai híd és a Rózsavölgyi alagút az un. Körvasútsori körúthoz kapcsolódó beruházások, a Körvasútsori körút megvalósításáról még elvi döntést sem hozott a föváros, bár az egyeztetési szakaszba került városfejlesztési koncepció prioritást adna neki. E szakasz azonban az új körúton belül nem élvez prioritást. Ha számíthatunk is e beruházások megvalósulására az csak tíz-tizenöt éves időtávlatban képzelhető el. A most kialakult konfliktus kezelésében ezek az elemek így csak hosszabb távú igéretekként, és nem reális megoldásokként szerepelhetnek.

A két, elvben lehetséges, de vizsgálatunkból kihagyott változat közül az első (A.) az ART-ben tervezett, teljes hálózat, aminek a Körvasút-menti körúthoz kapcsolódó elemeinek (Albertfalvai híd és Rózsavölgyi alagút) megépítése csak hosszabb távon elképzelhetö, de 10 éven belül a fenti 4 . változathoz hasonlóan nincs realitása, így a jelenlegi áldatlan helyzet kezelésére nem alkalmas. A második (B.) megegyezik az A-val, csak a Hamzsabégi utat nem építi meg. Megvalósítása - az elöző indoklás miatt - rövidtávon szintén nem várható. E két esetet (A és B alternatíva) a következö elemzésböl elhagyjuk, mert a négy változat kezelése, megoldásunkat jelentősen egyszerüsíti, és - mint látni fogjuk - eredményét nem változtatja meg alapvetóen.

\section{A játékosok a második szakaszban}

\section{A választók/lakosság}

$\mathrm{Az}$ átlag budapesti polgár lényegében nem változott az első szakasz óta. Amenynyiben az útvonalat használni kívánja, egyre jobban szembesülnie kell a problémás helyzettel, és a tömegkommunikáció is felhívja esetleg figyelmét az egyre élesebb ellentétre. Ennek ellenére a budapesti lakosok egy része valószínúleg továbbra sem érzi magát érintettnek.

A Hamzsabégi úti lakosok továbbra is gyöztesnek érezhetik magukat, mert személyes szinten nyertek lakókörnyezetük megvédésével. E nyereség továbbra is meghaladja azt az elvi veszteséget, amit az ősszvárosi hálózat kára jelent számukra. Érintettségük miatt azonban valószínüleg már érzékelik, hogy a csatározások még nem zárultak le.

$\mathrm{Az}$ Andor utcaiak továbbra is az igazi vesztesek, akik már érdekcsoportba szerveződtek és tiltakoznak is.

A környék többi lakosa is érzékeli, hogy új megoldás fog születni, így a lakók egy része közömbösségét feladva szintén civil érdekképviseletté egyesült.

Nyilvánvaló, hogy a fenti területi egységek érdeke részben eltér egymástól, és az is, hogy a csoportok mára jól értik a probléma lényegét. Ennek ellenére erőik egyesítésének érdekében közös szervezetet alakítottak Dél-Budai Polgári Szervezetek Környezetvédelmi Egyulttmüködési Fơruma (DKEF) néven, ahol kompromisszumos, közös nevezős érdeket képviselnek. Ez hivatalosan a fenti 4-es számú alternatívával egyezik meg. 
A politikusok

A kerületi politikus számára is látható, hogy tranzit forgalom vezetésére megoldást kell találni, és már az is biztos, hogy e megoldás nem az Andor utca lesz. Most már nem elég egyszerủen csak a tiltakozók mellé állni. Kérdéses azonban, hogy mi módon lehet a legkisebb vesztességgel ,véleményt váltani”.

Az egyre erősödő lakossági elégedetlenség miatt a Fővárosnál is elörébb került a kérdés a fontossági sorban. Ez egyenlỏre még szintén nem jelent megoldást. Mindössze néhány gyenge kompenzációs kísérlet történt, mint elvetélt próbálkozások egy pozitív végkifejletért.

Az élénkülő fővárosi érdeklődést egyenlőre legjobban az jelzi, hogy az ellenzéki politikusok közös nyilatkozatban támogatták a DKEF követeléseit.

\section{A bürokrácia}

A bürokrácia általában továbbra is a Hamzsabégi úti megoldás mellett lenne, csak nincs stratégiaja arra, hogy a többi szereplőt e megoldás elfogadására szorítsa.

A játékosok eredményei a második szakaszban

\section{TÁBLÁZAT}

Az egyes érdekek érvényesülésének pontértékei

(The Scores of Effectiveness of Individual Interests)

\begin{tabular}{|l|c|c|}
\hline & Érvényesülés pontértéke & $\begin{array}{c}\text { Nem érvényesülés } \\
\text { pontértéke }\end{array}$ \\
\hline Fontos személyes érdek & +5 & -5 \\
\hline Kevésbé fontos személyes érdek & +3 & -3 \\
\hline Közvetett érdek & +1 & -1 \\
\hline Közömbös & 0 & 0 \\
\hline
\end{tabular}

Forrás: saját adatok.

A második periódusban (1997-1998-ban) négy alternativát vizsgálunk. Első esetben az alternatívákat úgy pontozzuk, hogy feltételezzük az „önző” játékost, aki személyes érdeke szerint dönt, de az aktuális helyzettel szemben azt is feltételezzuik, hogy jól informált, tehát tényleges érdeke szerint tudja az alternatívákat súlyozni.

\section{TÁBLÁZAT}

Az egyes érdekcsoportok érdekeltségének mértéke különböző alternatívák esetén, feltételezve a jól informáltságot

(The Degree of Interest of Individual Concerns in Case of Different Alternatives, Assumed the Well-information)

\begin{tabular}{|l|c|c|c|c|}
\hline \multicolumn{1}{|r|}{ Alternativa } & 1. & 2. & 3. & 4. \\
\hline Érdekcsoport & & & & 0 \\
\hline Átlag budapesti lakos & +3 & +3 & +1 & 0 \\
\hline Hamzsabégi úti lakos & -5 & -5 & +5 & +5 \\
\hline Andor utcai lakos & +5 & +5 & -5 & -5 \\
\hline Többi XI. kerületi lakos & +3 & +3 & +1 & -3 \\
\hline Kerületi Hamzsabégi úti politikus & -5 & -5 & +3 & +3 \\
\hline Kerületi nem Hamzsabégi úti politikus & +3 & +3 & -5 & +1 \\
\hline Fóvárosi koalíciós politikus & +5 & +3 & -5 & -5 \\
\hline Fóvárosi ellenzéki politikus & -5 & -5 & +5 & +3 \\
\hline Hivatal & +5 & +3 & -3 & -3 \\
\hline
\end{tabular}

Forrás: sajảt adatok. 
Pallai Katalin : A dél-budapesti „közlekedési játék”,

avagy Dél-Buda közlekedési problémáinak stratégiai játék formájában való elemzése

Tér és Társadalom 12. évf. 1998/3. 133-151. p.

A pontok alapján úgy tünik, hogy alapvetöen van esély az elvben optimális 1-es számú megoldás győzelmére, amennyiben elérhető a szereplök megfeleló tájékoztatása. (Az egyszerüsített pontozás eredményét az sem változtatja meg, ha csak a lakossági csoportokat összegezzük és a pontok mögött álló csoportok résztvevőinek számával súlyozzuk a pontozást.)

Megpróbálhatjuk az egyes érdekcsoportok preferencia rendjét is felírni a fenti feltételek szerint:

6. TÁBLÁZAT

Az egyes érdekcsoportok preferencia rendje

(The Preference Hierarchy of Individual Concerns)

\begin{tabular}{|c|c|c|c|c|}
\hline Érdekcsoport $\quad$ Alternativa & Legjobb & 2. legjobb & 3. & $\begin{array}{l}\text { Legrosz- } \\
\text { szabb }\end{array}$ \\
\hline Átlag budapesti lakos & 1 & 2 & 4 & 3 \\
\hline Hamzsabégi úti lakos & 3 & 4 & 1 & 2 \\
\hline Andor utcai lakos & 1 & 2 & 3 & 4 \\
\hline Többi XI. kerületi lakos & 1 & 2 & 3 & 4 \\
\hline Kerületi Hamzsabégi úti politikus & 4 & 3 & 1 & 2 \\
\hline Kerületi nem Hamzs. úti politikus & 2 & 1 & 4 & 3 \\
\hline Fövárosi koalíciós politikus & 1 & 2 & 3 & 4 \\
\hline Fővárosi ellenzéki politikus & 3 & 4 & 2 & 1 \\
\hline Hivatal & 1 & 2 & 3 & 4 \\
\hline
\end{tabular}

Forrás: saját adatok.

Ez a táblák is egyszerüen csak azt mutatják, hogy megfelelö tájékoztatás esetén könnyen megszullethetne a jó döntés (vagy azt, hogy a tanulmányíró agya leegyszerüsíti a szituációt arra, amit ö helyesnek gondol).

Amennyiben ugyanezeket a táblákat nem a feltételezett, reális érdekek alapján, hanem a jelenlegi nyilatkozatok állításai szerint töltjük ki a következő variációt kapjuk:

\section{TÁBLÁZAT}

Az egyes érdekcsoportok érdekeltségének mértéke jelenlegi nyilatkozataik alapján (The Degree of Interest of Individual Concerns Based on Theirs Current Declaration)

\begin{tabular}{|c|c|c|c|c|}
\hline $\begin{array}{lll}\text { Érdekcsoport } & \text { Alternativa } \\
\end{array}$ & 1. & 2. & 3. & 4. \\
\hline Átlag budapesti lakos & +1 & +1 & -1 & 0 \\
\hline Hamzsabégi úti lakos & -5 & -5 & +3 & +5 \\
\hline Andor utcai lakos & -5 & -3 & -5 & +5 \\
\hline Többi XI. kerületi lakos & +3 & +3 & +1 & +1 \\
\hline Kerületi Hamzsabégi úti politikus & -5 & -3 & +3 & +5 \\
\hline Kerületi nem Hamzsabégi úti politikus & +3 & +3 & -5 & +1 \\
\hline Fóvárosi koalíciós politikus & +5 & +3 & -5 & -5 \\
\hline Fövárosi ellenzéki politikus & -5 & +3 & +3 & +5 \\
\hline Hivatal & +5 & +3 & -5 & -3 \\
\hline
\end{tabular}

Forrás: saját adatok. 
Az elöző táblázatokból jól látszik, hogy a jelenleg kinyilvánított vélemények alapján messze állunk az általunk jónak ítélt 1 -es számú és második helyre rangsorolt 2-es számú alternatívától. Helyettük a 4-es alternativa szerzett több pontot mind a lakosság, mind az összes ,játékos" véleményének összegzése alapján.

\section{TÁBLÁZAT}

Az egyes érdekcsoportok preferenciarendje a nyilatkozataik alapján (The Preference Hierarchy of Individual Concerns Based on Theirs Declaration)

\begin{tabular}{|c|c|c|c|c|}
\hline Érdekcsoport $\quad$ Alternativa & Legjobb & 2. legjobb & 3. & $\begin{array}{l}\text { Legrosz- } \\
\text { szabb }\end{array}$ \\
\hline Átlag budapesti lakos & 1 & 2 & 4 & 3 \\
\hline Hamzsabégi úti lakos & 4 & 3 & 1 & 2 \\
\hline Andor utcai lakos & 4 & 2 & 1 & 3 \\
\hline Többi XI. kerületi lakos & 1 & 2 & 4 & 3 \\
\hline Kerületi Hamzsabégi úti politikus & 4 & 3 & 2 & 1 \\
\hline Kerületi nem Hamzs. úti politikus & 2 & 1 & 4 & 3 \\
\hline Fóvárosi koalíciós politikus & 1 & 2 & 3 & 4 \\
\hline Fóvárosi ellenzéki politikus & 4 & 2 & 3 & 1 \\
\hline Hivatal & 1 & 2 & 4 & 3 \\
\hline
\end{tabular}

Forrás: saját adatok.

A preferencia-sorrendek azt mutatják, hogy amennyiben a 4-es alternatíva törölhetó lenne, akkor könnyen formálódhatna egyesség az 1-es vagy 2-es alternatíva mellett a döntés bármely szintjén.

\section{Stratégiák}

Amennyiben a fenti pontozás és preferencia sorokat helyesen feltételezzük, a táblák legegyszerúbb tanulsága az lehetne, hogy a játékosok megfelelỏ tájékoztatása megoldja a jelenleg kezelhetetlennek látszó problémát. Azt azonban jól lehet tudni, hogy a lakosság „megfelelob tájékoztatása" szinte lehetetlen abban az esetben, amikor a kérdésről az érdekelt csoportoknak rőgzült a véleménye, és azt kellene megváltoztatni egy olyan szituációban, amikor különbözỏ érdekcsoportok különbözö információkat akarnak a választókhoz eljuttatni. Így a „reális és megfelelö tájékoztatás", mint alternatíva kiesik.

Ha az első „igazi érdek” és a második „,vélt érdek” szerinti pontokat hasonlítjuk össze, az látható, hogy ,,igazi érdek” szerint 1-2-4-3, „vélt érdek” szerint 4-2 $-1-3$ a sorrend.

Amennyiben stratégiánkat a választók döntésére akarjuk építeni, feltételezhetjük, hogy a legnagyobb csoport, az átlag budapesti lakos alig mobilizálható, e számára nem fontosnak értékelt témában. Amennyiben el lehet hitetni az XI. kerulleti, és Andor utcai csoporttal, hogy a 4. számú alternatívának ebben a formájában nincs esélye (ami igaz is) ${ }^{14}$, akkor ók elvben a 2 . számú alternatíva mellé állíthatók, és igy a Hamzsabégi úti lakos és az öt képviselö, kerületi politikus esélyei is megváltoznak. Hiszen a Hamzsabégi úti lakosokon és a melléjuk álló, helyi politikuson kívül mindenki rangsorában az utolsó helyre kerül a 3-as változat. Vagyis az 1-es vagy 2es mellett kialakulhat a konszenzus, ami a Hamzsabégi út építését - így a probléma megoldását - jelenti. 
Pallai Katalin : A dél-budapesti „közlekedési játék",

avagy Dél-Buda közlekedési problémáinak stratégiai játék formájában való elemzése

Tér és Társadalom 12. évf. 1998/3. 133-151. p.

Amennyiben a döntéshozási mechanizmus oldaláról indulunk ki - ahol a Főváros a fejlesztö/finanszírozó, és a kerület az engedélyezö, a hivatal a döntés elökészítö -, a Fővárosnak lehetősége van pozitív döntést hozni bármiről, de a kerületnek csak vétójoga van, a bürokrácia esetleg a döntés lágy befolyásolására képes. Mindhárom figyeli a lakossági reakciót.

Az 1-es altematívát nem fogadná el a kerületi politikus, és a fỏvárosi ellenzék is mindent megtenne ellene. Amennyiben azonban bizonyithatóvá válna, hogy a 4-es alternatíva irreális, a fóvároson belül konszenzus alakulhatna ki a 2-es mellett, és ez a változat a kerület is számára is elfogadható lehetne. İgy elvben erröl megegyezés, így problémánkra megoldás születhetne.

Vagyis - amennyiben feltételezéseink megállják a helyüket - az eredmény rendkívull érdekes: ahhoz, hogy elfogadhatóvá váljék, hogy az Andor utca helyett a Hamzsabégi út mégis az optimális helye a Lágymányosi híd levezetésének - vagyis az Andor utca kiszélesítése helyett (vagy mellett), mégis meg kellene a Hamzsabégi utat építeni -, egy e kérdéstől elvben és földrajzilag is távolabbi projektröl - az Albertfalvai hídról - kellene elöször megkérdőjelezhetetlen döntést hozni. Amenynyiben a konfliktus résztvevői számára bizonyossá válna, hogy belátható idön belül az Albertfalvai híd nem épül meg, és csak azzal a feltétellel épül bármikor is, ha a Rózsavölgyi alagút is megépülhet, azonnal átrendezödnének mind a vélt, mind az igazi érdekek (felbomlana a DKEF), és létrehozható lenne a Hamzsabégi út megépítéséhez szúkséges konszenzus.

A kulcs így a kisstílú, helyi csatározás helyett hosszi-, de legalább középtávú Városfejlesztési Koncepció elfogadása Budapest számára, és a hosszútávú stratégiai tervezés nyilvánosságának és hitelének megteremtése, ami a zsákutcás vágyálmokat elüzi. Ez azonban már messze vezet a témánktól, ami csak a kialakult helyzetet és lehetséges megoldásait próbálta elemezni.

A fentiekben bemutatott modell, olyan, mint fejben sakkozni, "gondolati stratégiai játék", amely kapcsolatot próbál teremteni a szakmai tervezés javaslatai és a megvalósítás érdekében mozgósitható politikai eszközök között. Fontosságát az adja, hogy Magyarországon a településfejlesztési gyakorlat, csak lassan, akadozva tud a megváltozott, demokratikus döntéshozási rendszerhez alkalmazkodni. Helyenként a "közösségi tervezés" (cooperative planning) módszerének elemei már alkalmazásra kerülnek a településfejlesztési koncepciókban, az alternatívák befolyásolásának politikai eszkőzeit azonban a tervezők és döntéshozók még alig használják ki.

Különősen eszköztelennek látszanak a települések a konfliktusszituációk feloldásában és a településfejlesztés demokratikus döntéshozási rendszereiben természetesen és gyakran felmerüló NIMBY ${ }^{15}$ típusú problémák kezelésében. Az itt bemutatott modell egy olyan módszer lehet, amelynek alapján nemcsak konfliktusos helyzetekben érdemes végiggondolni a lehetséges megoldásokat és kompromisszumokat. A legfontosabb üzenet az lehetne, hogy már a tervezés fázisában kellene a feltételezhetően kialakuló konfliktusos és NIMBY helyzeteket hasonló módon végiggondolni, a javaslatokban a szakmai "elfogadhatóság" és a politikai "kivitelezhetőség" kritériumait akár kompromisszumok árán is egyesíteni, végül a tervek PR munkáját - felkészülve a konfliktusra - még kialakulása elött megkezdeni. 
Pallai Katalin : A dél-budapesti „közlekedési játék”,

avagy Dél-Buda közlekedési problémáinak stratégiai játék formájában való elemzése

Tér és Társadalom 12. évf. 1998/3. 133-151. p.

\section{Jegyzetek}

${ }^{1}$ Ez az idézett kijelentés, amivel Amartya Sen 1995-ben az American Economic Association kongreszszusát megnyitó elnőki beszédet indította, jól osszzegzi, mind Keneth Arrow - a diszciplína szempontjából meghatározó jelentőségü - Lehetetlenségi Tételének (Arrow 1951) hatását, mind az abból induló, máig le nem zárt probléma és elvi vita következményeit.

${ }^{2}$ Duncan Blacket - aki kózgazdaságtanból kỏlcsőnvett módszereket kezdett használni hagyományos politikaelméleti problémák megoldására (Black 1958) - nevezhetjuk mind a Kozösségi Választások Elmélete (Public Choice Theory), mind az itt említett Politikai Piac Elmélet (Political Market Theory) megalapozójának. Ezen utóbbi elmélet a politikai tevékenység tanulmányozására a kőzgazdaságtanban alkalmazott piac modellt használja, amelyben a választókat, politikusokat és hivatalnokokat $e$ politikai piac keresleti és kínálati oldalon álló, érdekérvényesítö, racionális szereplöinek feltételezi. $\mathrm{E}$ Politikai Piac Elmélet tơbb fontos elemére és jelentös szerzőjére tơrténik majd utalás a szövegben, a késöbbiekben. (Downs, Tullock, Niskanen, ect).

${ }^{3}$ E gondolat első fontos megfogalmazása Anthony Downstól ered. (Downs 1959) Később tơbb jelentős szerző munkája gazdagitotta és fejlesztette e gondolatot egy mind kimunkáltabb elméletté a választásról, a választókról, és le hetséges viselkedésakröl. (Tullock, Hirschman, stb.)

4

E kijelentés nem a bürokráciára vonatkozó korábbi elméletekre hivatkozik, amelyek a bürokráciát alapvetően tekintély kapcsolatra alapozott hierarchikus rendszernek tekintették (Weber 1946), hanem a bürokráciára vonatkozó újabb elméletekre, és leginkább a politikai piac elméletnek a kínálati oldalból kiinduló részére, amely a hangsúlyt a kormányzat választott tisztségviselói és hivatali részének konfliktusára helyezi, és elméletét alapvetöen ezen érdekkonfliktus kơvetkezményeire építi. (Niskanen 1971)

5 A számviteli szabályozásnak megfelelö, és általánosan alkalmazott tételes költségvetésből csak a tevékenységekre fordított kiadások (input adatok) derülnek ki, fuggetlenul az általuk létrehozott eredményektöl / hatásoktól. E problémát vagy megfelelö monitoring rendszerrel, vagy más kőltségvetési rendszerek alkalmazásával lehet kezelni. Ilyen pl. a programkőltségvetés, amely tevékenységek és létrehozott eredmények (outputok) szerint próbálja rendszerezni a kiadásokat.

${ }^{6}$ A korábban is említett elméletek szerint az aszimmetrikus információ alkotó eleme a tisztségviselöhivatal viszonynak. Ahogy a piaci versenyben az aszimmetrikus információ a piac kudarcainak egyik alapvető oka, a politikai piac elméletében is a piac kudarcához, így a piac szabályozó és hatékony eredményeket biztosító képességének elvesztéséhez vezethet. (Niskanen 1971)

7 Öt „hobbistának” nevezhetjük, mert ä lényegében az általa feltételezett „kozjót” (kðzjószágot) próbálja maximalizálni.(Tullock 1987)

${ }^{8}$ E vita elemeit jól dokumentálják a Föváros egyidejủ dơntései, és a szakfolyóiratokban és napilapokban megjelent állásfoglalások.

${ }^{9}$ Lényegében minden elmélet megegyezik abban, hogy a jól szervezett érdekcsoport arányos súlyánál lényegesen nagyobb hatást képes elérni. (Stiegler 1971) A további elemzés leginkább Peltzman Tơrvényi Szabályozási Elméletén alapul, amelyben az eredményt végal a kritikusan érintett és haszonélvezó csoportok, támogatási és ellenzési fuggvényeinek egyensúlyi pontja adja. (Peltzman 1976)

${ }^{10}$ A Hamzsabégi út építése közvetlenül, negatívan az út közvetlen környezetében lakó, mintegy háromezer lakost érintette volna. Ezzel szemben, ha a forgalomcsillapitási hatást tekintjük, az eröteljesen érvényesült volna a kerulet Bocskai út felé esỏ részén, $\mathrm{kb}$. 16 ezer lakost érintve, és a teherforgalmat a Ferenc körút-Üllöi úti szakaszon is csökkentette volna, igy közvetett pozitív hatásában mintegy 27 ezer embert érintve.

"Arrow kizárja a kardinális értékek használatát, igy csak az egyszerū preferencia kapcsolatok léteznének, vagyis a pontszámok bármely érték szerinti értelmezése lehetetlen lenne.

${ }^{12}$ Arrow lehetetlenségi tétele bebizonyitja, hogy az egyéni preferenciákat nem lehet a szuverenitás és racionalitás alapvető feltételeinek teljesủlése mellett "korrekt" módon társadalmi választásokká egyesíteni. (konzisztencia, universalitás, diktatúra-mentesség, irreleváns alternatíváktól való fuggetlenség) Így már a lakossági csoportok preferenciái, vagyis a csoportokra vonatkozó aggregálás sem férne bele a szigorúan vett elméleti keretbe.

${ }^{13}$ A társadalmi választások elmélete szerint a "preferencia" az, amit az "érdekérvényesitō" szerepló kedvezőbbnek tart, igy az elmélettel teljesen ellentétes a vélt és igazi érdek szétválasztása. Az elmélet racionálisnak a konzisztens egyéni választást tekinti, annak kạlső mérték szerinti megkérdöjelezhetőségét kizárja. "Hatékonynak" az egyéni preferenciákat legjobban aggregáló dontést nevezi. 
Pallai Katalin : A dél-budapesti „közlekedési játék”,

avagy Dél-Buda közlekedési problémáinak stratégiai játék formájában való elemzése

Tér és Társadalom 12. évf. 1998/3. 133-151. p.

${ }^{14}$ Az Albertfalvai híd építésére 10 éven belul nincs esély, és utána is csak akkor, ha alagút is épulhet.

${ }^{15}$ NIMBY ("not in my backyard", vagyis "ne az én kertem mellett"). Azt a helyzetet jelzi a telepuléspolitikában, amikor a nagyobb teruletegység szempontjából szukséges, azonban lokálisan jelentkezó negativ externiáliával rendelkező fejlesztést elvben mindenki elfogadja, csak éppen a saját lakóhelyén való létesités ellen tiltakozik.

\section{Irodalom}

Arrow, K. (1951) Social Choice and Individual Values, New Haven: Yale UP

Black, D. (1958) The Theory of Commitees and Elections. Cambridge: Cambridge University Press.

Cullis, J. and P. Jones (1992) Public Finance and Public Choice, London: McGraw-Hill.

Dalmy, T. (1995) A Lágymányosi hídberuházás megvalósítása, Közlekedésépités- és Mélyépitéstudományi szemle, XLV. 10-11. (1995. October-November) 357-360. o.

Downs, Anthony (1959) An Economic Theory of Democracy, New York: Harper and Row.

Niskanen, W. (1971) Bureaucracy and Representative Government, Chicago: Aldine-Altherton.

Peltzman (1976) Toward a More General Theory of Regulation, Journal of Law and Economics, 19

(August), 211-240. 0.

Schulek, J. (1995) A Lágymányosi híd csatlakozó úthálózata, Kozlekedésépités- és Mélyépitéstudományi szemle, XLV. 10-11. (1995. October-November) 364-370. o.

Sen, A. (1995) Rationality and Social Choice, in: American Economic Review, 85, 1-24. o.

Stevens, J. (1993) The Economics of Collective Choice, Boulder: Westview.

Stiegler (1971) The Theory of Economic Regulation, Bell Journal of Economics 2 (Spring) 3-21. o.

Tullock, G. (1987) Public Choice, in: Eatwell, J., Milgate, M., Newman, P. eds, The New Palgrave, a Dictionary of Economics, UK: Macmillian Press Limited.

Weber, M. (1946) Bureaucracy, in: H.H. Gerth and Wright Mills, eds., From Max Weber: Essays on Sociology, 196-244. 0., New York: Oxford University Press. 